http://e-journal.stit-islamic-village.ac.id/index.php/JM2PI

\title{
Analisis Peran Gawai dalam Membantu Perkembangan Belajar Siswa
}

\author{
Siti Nourrochmatul Umah \\ Program Studi Pendidikan Agama Islam, STIT Islamic Village Tangerang \\ Email: sitinourrochmatulumah@ymail.com
}

Received: September, 2020.

Accepted: Oktober, 2020.

Published: November, 2020

\begin{abstract}
The purpose of this research is to analyze the role of devices in helping students' learning development.

The research is library research, this research was conducted by conducting and examining in depth through an analytical description of the role of devices in helping students' learning development. The subjects of this study were students from various levels of education. Data sources come from books, journals, articles, previous theses, and websites. While data analysis was carried out by means of descriptive analysis.

The results showed that devices played a very important role in helping students learning development. This is evidenced by the 4.0 industrial revolution which is usually called the digital age. The field of education is one aspect that must be sensitive to technological developments.
\end{abstract}

Keywords: Role of Device, Learning Development, Technology, Digital Age.

\section{ABSTRAK}

Tujuan dari penelitian ini adalah untuk menganalisis peran perangkat dalam membantu perkembangan belajar siswa.

Penelitian ini merupakan penelitian pustaka, penelitian ini dilakukan dengan melakukan dan menelaah secara mendalam melalui deskripsi analitis tentang peran perangkat dalam membantu perkembangan belajar siswa. Subjek penelitian ini adalah siswa dari berbagai jenjang pendidikan. Sumber data berasal dari buku, jurnal, artikel, skripsi, dan website sebelumnya. Sedangkan analisis data dilakukan dengan cara analisis deskriptif.

Hasil penelitian menunjuke.kan babwa gawai memegang peranan yang sangat penting dalam membantu perkembangan belajar siswa. Hal tersebut dibuktikan dengan revolusi industri 4.0 yang biasa disebut era digital. Bidang pendidikan merupakan salah satu aspek yang harus peka terhadap perkembangan teknologi.

Kata Kunci: Peran gawai, perkembangan belajar, teknologi, era digital. 


\section{PENDAHULUAN}

Pendidikan saat ini tengah berada di era globalisasi yang kian hari semakin pesat perkembangannya, seperti yang dikatakan oleh Heri Murtomo (2018) bahwa "era globalisasi yang tengah melanda dunia termasuk Indonesia berlangsung sangat cepat sehingga menuntut kemampuan manusia unggul yang mampu mensiasati dan mengantisipasi kemungkinan-kemungkinan yang sedang dan akan terjadi."

Manusia yang unggul dan berintegritas akan dihasilkan melalui proses pendidikan yang dijalaninya dari jenjang pendidikan dasar hingga pendidikan tinggi. Hal ini membuat khususnya para pelajar, pelaksana pendidikan dan akademisi harus peka atau sadar terhadap perkembangan teknologi dan informasi yang ada di Indonesia saat ini, sehingga dapat memberikan inovasi baru bagi dunia pendidikan khususnya para pendidik untuk memberikan pengajaran yang lebih berkualitas efektif dan efisien.

Indonesia merupakan negara yang tengah merasakan perkembangan teknologi dan komunikasi, dan telah mengaplikasikannya dalam dunia pendidikan. Untuk bersaing dengan negara lain tentunya Indonesia membutuhkan generasi-generasi yang kelak mampu bersaing dengan bangsa lain dalam memajukan bangsa, maka dari itu dibutuhkan kesadaran akan teknologi yang tengah berkembang saat ini. Salah satu teknologi yang ada dan berkembang dalam dunia pendidikan adalah gawai. Hadirnya gawai mampu memberikan manfaat dan melengkapi fasilitas belajar mengajar guna mencapai tujuan belajar yang efektif dan efisien. Lebih dari itu, bahkan gawai dapat memenuhi kebutuhan belajar kognitif, afektif dan psikomotorik, Nida (2013:13) mengatakan "Belajar merupakan proses internal yang kompleks. 
Yang terlibat dalam proses internal tersebut adalah seluruh mental yang meliputi ranah kognitif, afektif, dan psikomotorik".

\section{METODE}

Penelitian ini menggunakan studi kepustakaan (Library Research). Penelitian pustaka merupakan metode dalam pencarian, mengumpulkan dan menganalisis sumber data untuk diolah dan disajikan dalam bentuk laporan Penelitian Kepustakaan. (Rina Hayati, 2019). Penelitian ini menggunakan teknik analisis deskriptif, data yang dikumpulkan dengan menggunakan teknik deskriptif analisis adalah berupa kata-kata, gambar dan bukan angka-angka. (Bina Mukhlas, 2018). Analisis berarti mengkaji data yang diperoleh dari sumber data baik itu buku, jurnal, skripsi, artikel dan lain-lain untuk kemudian di analisis menggunakan teknik deskriptif.

\section{PEMBAHASAN}

Gawai atau yang sering disapa dengan sebutan gadget Wikipedia (2020) mempublikasikan bahwa gadget atau gawai adalah "suatu peranti atau instrumen yang memiliki tujuan dan fungsi praktis yang secara spesifik dirancang lebih cangggih dibandingkan dengan teknologi yang diciptakan sebelumnya”. Menurut Derry Iswidhamanjaya (2014) "Gadget adalah sebuah perangkat atau instrumen elektronik yang memiliki fungsi praktis terutama untuk membantu pekerjaan manusia"

Perkembangan zaman teknologi ini sangat maju dan pesat sehingga semua orang dapat mudah mendapatkan informasi. Beberapa sekolah yang penulis temui sudah mulai mengharuskan menggunakan gawai, karena untuk memberikan kemudahan bagi guru dalam kegiatan belajar dan mengajar di sekolah. 
Kebutuhan siswa saat ini tidak hanya kebutuhan yang selalu kita temui sehari-hari sebelum adanya gawai, kini gawai menjadi sesuatu yang penting dan wajib dimiliki oleh anak sekolah. Seperti pendapat Choirul Latifa (2019) "Sekarang ini gawai menjadi kebutuhan primer bagi siswa SMP/MTsN, SMAN/MAN, SMK. Gawai digunakan di sekolah dengan tujuan untuk memepermudah siswa, jika siswa mengerjakan tugas dengan baik maka mendapatkan nilai yang maksimal". Penulis setuju dengan argumen diatas, bahwa siswa akan mendapatkan nilai maksimal jika mampu menyelaraskan daya fikirnya dengan memanfaatkan teknologi dan informasi dengan baik sebagaimana mestinya.

Menurut Maya Ferdiana Rozalia (2017:723) intensitas merupakan "kadar keseringan seseorang dalam melakukan suatu hal". Pada penelitian kali ini, intensitas penggunaan gawai merupakan kadar keseringan siswa dalam memanfaatkan gawai baik untuk kepentingan belajar maupun yang lainnya. Fakta menunjukkan bahwa disetiap hari seorang anak dapat menghabiskan lebih dari tujuh jam penggunaan gadget dan teknologi ilmu komunikasi dalam kehidupan sehari-hari baik untuk kepentingan pendidikan, berkomunikasi atau bermain game (Saruji, dkk, 2017).

Berdasarkan penelitian yang dilakukan oleh Beauty Manumpil, dkk (2015:2) mereka mengatakan "dari 10 siswa yang diwawancarai, 8 menggunakan gawai lebih dari 3 jam terhitung dari jam 10:00-14:00". Sedangkan menurut Zimic (2011) "Remaja menghabiskan waktu 1,5-3 jam setiap hari hanya untuk bermain sosial media seperti Facebook, Twitter, Path, Instagram dan We-chat". Sementara itu, Saifuddin Chalim \& E.Oos M.Anwas (2018: 35) mengungkapkan bahwa "sebagian besar siswa menggunakan gawai lebih dari dua jam setiap hari, hanya sebagian kecil saja atau 13,9\% yang penggunaannya kurang dari satu jam”. 
Dari data tersebut di atas, dapat penulis simpulkan bahwa intensitas penggunaan gawai oleh siswa pada umumnya cukup tinggi, lebih dari 2 jam sekali dalam sehari, dengan demikian gawai tentunya memiliki potensi yang besar untuk membantu perkembangan belajar siswa.

Menurut Marbun dalam Intan Fitria (2019:3) "Media massa merupakan faktor yang berpengaruh terhadap keberhasilan siswa". Gawai diakui dapat memberikan banyak manfaat, namun terkadang gawai juga memberikan dampak yang merugikan siswa karena begitu banyaknya informasi yang disajikan melalui gawai.

Gawai sudah menjadi separuh kehidupan bagi hampir setiap orang, tak terkecuali bagi siswa. Pasalnya, berdasarkan survei yang dilakukan oleh Kominfo bersama dengan UNICEF dan Universitas Harvard, AS. Dari survei itu menyebutkan, "sebanyak 98 persen anak dan remaja mengaku tahu tentang internet, dan 79,5 persen di antaranya adalah pengguna internet". (Kominfo, 2014).

Sesuai dengan kurikulum 2013 kini guru tidak lagi menjadi satu satunya narasumber atau sumber utama dalam kegiatan belajar mengajar yang disebut dengan komunikasi satu arah yakni guru menerangkan kemudian para siswa mendengarkan namun kini guru hanya menjadi fasilitator bagi siswa ketika kegiatan belajar mengajar berlangsung. Kurikulum yang digunakan saat ini lebih menekankan agar siswa lebih aktif, kreatif dan mampu belajar, berlatih, dan mengembangkan wawasan ilmu pengetahuan yang dimilikinya.

Seringkali guru dihadapkan pada materi yang harus menggunakan media pembelajaran guna untuk memvisualisasikan materi yang akan diajarkan. Dalam hal ini guru dan siswa dikatakan sama-sama membutuhkan gawai (laptop, smartphone) untuk dijadikan sebagai media pembelajaran ketika proses pembelajaran berlangsung. Selain itu, meningkatkan antusias siswa untuk 
semangat belajar dibutuhkan penyajian materi yang menarik perhatian siswa, sehingga siswa lebih mudah memahami materi yang disampaikan.

Dalam hal ini, gawai memiliki peran untuk membantu baik itu guru maupun siswa untuk menjadikan gawai sebagai alat atau media pembelajaran, karena didalamnya gawai memiliki banyak sekali fitur yang mendukung untuk menyajikan data atau materi yang dilengkapi dengan teks, animasi, grafis, audio, dan video. Sehingga guru mampu mengintegrasikan fitur-fitur diatas.

Pada awalnya gawai tak menjadi suatu hal yang dibutuhkan bagi siswa, namun kini setelah sistem pembelajaran berubah, kini gawai menjadi salah satu kebutuhan bagi siswa untuk kepentingan belajarnya baik di sekolah maupun di rumah. Poses pembelajaran yang saat ini dilakukan dikelas tak terlepas dari peranan gawai. Multimedia storytelling menjadi salah satu metode penyampaian materi yang disampaikan oleh guru melalui gawai. Menurut Neni Kusuma Nugraheni (2017:32) “ informasi yang didapatkan oleh siswa melalui teknologi berbasis komputer adalah melalui tayangan di monitor. Adapun Aplikasi-aplikasi yang diterapkan dalam pembelajaran yang memanfaat komputer digolongkan menjadi 5 klasifikasi yaitu:

a. Tutorial, sebagai gambaran atau tutor bagi siswa untuk belajar

b. Latihan dan pengulangan, berguna untuk membantu siswa agar memahami materi yang disampaikan sebelumnya

c. Simulasi, memberikan gambaran atau model dari peristiwa.

d. Games, memberikan kesempatan mengaplikasikan pengetahuan yang baru dipelajari

e. Percobaan atau eksperimen, sama halnya dengan simulasi namun lebih menekankan kepada kegiatan yang bersifat eksperimentasi.

Chandra Anugrah Putra (2017:4) "Gadget ini bisa menjadi modal bagi guru dalam mengembangkan kreatifitasnya dalam mengajar". Maka dari itu 
perkembangan teknologi saat ini harus betul betul bisa dimanfaatkan, guru dan siswa diharapkan sudah faham mengenai sistem pembelajaran dengan menggunakan gawai sebagai media pembelajaran. Siswa mendapatkan stimulus untuk perkembangan belajarnya melalui materi pembelajaran yang disampaikan oleh guru. Maka dari itu, semakin menarik perhatian materi yang disampaikan semakin tinggi tingkat antusias siswa untuk belajar. Selain itu siswa juga mampu mengembangkan potensi-potensi yang ada pada dirinya dalam menggunakan gawai.

Manfaat gawai untuk perkembangan belajar siswa benar adanya, dilansir di digikidz.id dalam Tri Suhardi dan Esti Utami (2019:119) “ada beberapa manfaat media komputer untuk anak, mereka menjadi senang belajar, mampu mengoperasikan olah kata dan angka, melatih untuk masuk ke dunia kerja, mendapat pembelajaran keagamaan".

\section{SIMPULAN}

Setelah melakukan analisis data pada penelitian mengenai peran gawai dalam membantu perkembangan belajar siswa, maka dapat penulis tarik kesimpulan sebagai berikut:

1. Intensitas penggunaan gawai oleh siswa pada umumnya cukup tinggi, hal ini sangat membantu dan berpotensi untuk membantu siswa dalam proses pembelajaran di sekolah maupun proses belajar mandiri baik di lingkungan rumah, maupun masyarakat. Bila sedang di sekolah biasanya siswa di izinkan untuk menggunakan gawai saat jam pembelajaran bila dibutuhkan, saat jam istirahat dan pulang sekolah. Namun perlu diperhatikan intensitas penggunaannya oleh guru maupun orang tua, gawai tetap digunakan sewajarnya dan sebagaimana mestinya. Karena ketika di rumah, siswa dapat dengan bebas menggunakan gawai tak terbatas oleh ruang dan waktu. 
Maka dari itu, orang tua berperan untuk mendampingi siswa dalam menggunakan gawai dirumah, dalam artian memberikan batasan waktu untuk siswa menggunakan gawai.

2. Antusias siswa dalam menggunakan gawai sangatlah tinggi, hal ini dibuktikan dengan maraknya penggunaan media sosial dan aplikasi-aplikasi yang tersedia pada gawai, selain itu dibuktikan juga dengan era digital seperti sekarang ini sehingga siswa mau tidak mau harus memiliki salah satu dari rangkaian gawai yang juga dipergunakan untuk kepentingan belajarnya di sekolah. Namun sayangnya siswa masih belum seluruhnya mampu memanfaatkan keberadaan gawai untuk perkembangan belajarnya. Agar peran gawai untuk perkembangan belajar dapat dirasakan oleh siswa, perlu adanya kesadaran dalam diri siswa itu sendiri, motivasi, pengawasan, dan bimbingan dari orang tua, guru, dan orang-orang terdekat siswa.

3. Gawai sangat berperan dalam perkembangan belajar siswa karena, melalui gawai siswa mampu memenuhi dan meningkatkan kebutuhan perkembangan kognitif, afektif, dan psikomotorik secara mandiri, ataupun melalui guru, orang tua, dan orang lain. Gawai digunakan untuk kepentingan belajar, dan digunakan ketika proses pembelajaran bila dibutuhkan. Siswa dapat dengan bebas menggali ilmu pengetahuan dan wawasan secara luas melalui gawai namun perlu juga dibatasi dalam penggunaannya karena efek radiasi yang dipancarkan oleh gawai cukup berbahaya bagi kesehatan siswa. 


\section{REFERENSI}

Chalim, S., \& Anwas, EOM. (2018). Peran Orangtua dan Guru dalam Membangun Internet sebagai Sumber Pembelajaran. 14 (1) 35. Diperoleh pada 24 Juli 2020, dari google.scholar.com

Derry, I. (2014). Bila Si Kecil Bermain Gadget: Panduan Bagi Orang Tua Untuk Memahami Faktor-Faktor Penyebab Anak Kecanduan Gadget. Google Book.

Fitria, I. (2019). Hubungan Antara Intensitas Penggunaan Gadget Dengan Prestasi Belajar Siswa MAN 1 Bengkalis. Skripsi, UIN SUSKA: Riau

Harahap, N. (2014). Penelitian Kepustakaan. 08 (01) 68. Diperoleh pada 22 Mei 2020, dari media.neliti.com

Hayati, R. (2019). Penelitian Kepustakaan (Library Research) Macam, dan Cara Menuliskannya. Diperoleh pada 16 Mei 2020, dari penelitianilmiah.com

Kominfo. (2014). Riset Kominfo dan UNICEF Mengenai Perilaku Anak dan Remaja Dalam Menggunakan Internet. Diperoleh pada 20 Juli 2020, dari kominfo.go.id

Manumpil, B., Ismanto, Y., \& Onibala, F. (2015). Hubungan Penggunaan Gadget dengan Tingkat Prestasi Siswa di SMA Negeri 9 Manado. 3 (2) 2. Diperoleh pada 26 Juli 2020, dari ejournal.unsrat.ac.id

Mukhlas, B. (2018) Metode Library Research. Universitas Islam Negeri Maulana Malik Ibrahim Malang, skripsi. Diperoleh pada 30 Mei 2020, dari www.academia.edu 
Murtomo, Heri. (2018). Strategi Pendidikan di Era Globalisasi. Diperoleh pada 06 Maret 2020, dari http://diskuspendidikan.blogspot.com/2018/12/strategi-pendidikandi-era-globalisasi.html

Nidawati. (2015). Belajar Dalam Perspektif Psikologi dan Agama. 1 (1) 13. Diperoleh 11 Maret 2020, dari jurnal.ar-raniry.ac.id

Nugraheni, NK. (2017). Multimedia Pembelajaran Digital Untuk Meningkatkan Antusiasme Siswa Dalam Belajar. Diperoleh pada 24 Juli 2020,dari hipkinjateng.org

Putra, CA. (2017). Pemanfaatan Teknologi Gadget Sebagai Pembelajaran. 2 (1) 4. Diperoleh pada 24 Juli 2020, dari umpalangkaraya.ac.id

Rozalia, MF. Hubungan Intensitas Penggunaan Gadget dengan Prestasi Belajar Siswa Kelas V Sekolah Dasar. 5 (2) 724. Diperoleh pada 26 Juli 2020, dari ejournal.umm.ac.id

Saruji, M. A, dkk. (2017). Impact Of ICT And Electronic Gadget Among Young

Suhardi, T., \& Utami, E. (2019). Ayah \& Bunda: Mengatasi Kecanduan Gadget Pada Anak, Peran Orang Tua, dan Cara Mendidik Anak di Era Digital. Semarang: Syalmahat Publishing

Zimic, S. (2011). Memahami Interaksi Remaja dengan Internet. Jakarta: YPMA. 